\title{
Orbital Contusion
}

National Cancer Institute

\section{Source}

National Cancer Institute. Orbital Contusion. NCI Thesaurus. Code C118708.

Bruising of the skin and soft tissue surrounding the eye. 